\title{
THE MICROBIAL COMMUNITY STRUCTURE OF THE DUPNISA CAVE IN KIRKLARELI, TURKEY
}

\author{
STUKTURA MIKROBNE ZDRUŽBE V JAMI DUPNISA, \\ KIRKLARELI, TURČIJA
}

\author{
Nihal DOĞRUÖZ-GÜNGÖR ${ }^{*}$
}

\begin{abstract}
UDC 579:551.44(560)

Nihal Doğruöz-Güngör: The microbial community structure of the Dupnisa cave in Kirklareli, Turkey

Cave ecosystems count to be extreme environments due to their stable temperature, darkness, high humidity rates, and limited organic materials. In this context, these ecosystems represent invaluable laboratories for microbiological studies. Although there are common features between the microorganism groups obtained from the culture-based microbiological studies conducted in the caves and the groups highlighted through molecular methods, the microorganism groups determined through this last method are richer. The detected microorganisms are variable depending on the characteristics of each cave. The aim of this study is to determine the microbial diversity in samples taken from 5 different regions (including regions visited by tourists) of Dupnisa Cave and to reveal the differences between these regions. This is the first microbiological study running in cave sediments of Dupnisa Cave System situated in the north-western of Turkey. In this study, using the Illumina MiSeq next-generation sequencing approach for analyses of Dupnisa Cave samples, 14 phyla and 298 genera as well as 2 phyla and 20 genera can be attributed to bacterial and archaea OTUs, respectively. Moreover, the bacterial community is dominated by the phyla Proteobacteria, Actinobacteria, Bacteroidetes, Gemmatimonadetes, Firmicutes, Nitrospirae, Chloroflexi and Acidobacteria distributed with $1 \%$ and above. Archaeal community is represented by Thaumarchaeota and Euryarchaeota phyla. Proteobacteria is the most dominant bacterial phylum and Thaumarchaeota dominates the archaeal phyla. The highest number of types of bacteria according to Chao 1 richness estimation index were found at point AF (cave entrance / sediment), and that of types of archaea were found at point F2 (touristic area 2 / cave sediment). F2 was determined as the sampling point with the highest diversity of archaeal and bacterial genera according to Shannon-Wiener diversity index. Key words: cave microbiology, bacterial diversity, archaeal diversity, next generation metagenomic sequencing.
\end{abstract}

Izvleček UDK 579:551.44(560)

Nihal Doğruöz-Güngör: Struktura mikrobne združbe v jami Dupnisa, Kırklareli, Turčija

Stabilna temperatura, tema, velika zračna vlaga in omejena količina organske snovi so dejavniki, ki jamski ekosistem opredelijo kot ekstremno okolje in mu dajejo velik pomen v mikrobioloških študijah. Čeprav so bili izsledki študij z gojitvenimi metodami $\mathrm{v}$ jamah podobni izsledkom, pridobljenim z molekularnimi metodami, so zadnjenavedene omogočile določitev pestrejšega nabora mikroorganizmov. Spremenljivost mikroorganizmov se razlikuje glede na značilnosti posamezne jame. Cilj te študije je opredeliti raznovrstnost mikrobov $\mathrm{v}$ vzorcih iz petih predelov (vključno s turističnim predelom) jame Dupnisa in odkriti razlike med temi predeli. To je prva mikrobiološka študija jamskih sedimentov iz jamskega sistema Dupnisa na SZ Turčije. S sekvenciranjem Illumina Miseq naslednje generacije je bilo 14 debel in 298 rodov pripisanih bakterijskim OTU, 2 debli in 20 rodov pa arhejskim OTU. V bakterijski združbi prevladujejo debla Proteobacteria, Actinobacteria, Bacteroidetes, Gemmatimonadetes, Firmicutes, Nitrospirae, Chloroflexi in Acidobacteria, združbo arhej pa zastopata debli Thaumarchaeota in Euryarchaeota. Med bakterijami je vodilno deblo Proteobacteria, pri arhejah pa Thaumarchaeota. Indeks pestrosti Chaol kaže na največjo pestrost bakterij na vzorčnem mestu AF (vhod v jamo/sediment), največjo pestrost arhej pa na vzorčnem mestu F2 (turistični del 2/jamski sediment). Glede na Shannon-Wienerjev indeks pestrosti je bila največja raznolikost rodov arhej in bakterij na vzorčnem mestu F2.

Ključne besede: jamska mikrobiologija, raznovrstnost bakterij, raznovrstnost arhej, sekvenciranje naslednje generacije.

1 Istanbul University, Faculty of Science, Department of Biology, 34134, Istanbul, Turkey, e-mail: ndogruoz@istanbul.edu.tr

* Corresponding author

Received/Prejeto: 06.04.2020

DOI: $10.3986 /$ ac.v49i2-3.8575 


\section{INTRODUCTION}

Cave habitats are defined as dark underground gaps with openings to the surface and characterized by limited amount of organic matter as well as large mineral surface areas (Palmer 1991; Northup \& Lavoie 2001). Therefore, they are considered as extreme environments for the inhabitation of certain microorganisms (Lee et al. 2012). Organic matter entrance, essential for sustaining life in caves, is facilitated via dripping water, underground rivers, visitors and animals, particularly bats (Groth et al. 1999; Groth \& Saiz-Jimenez 1999; Barton 2006). However, in some caves, lithotrophic bacteria play a primary role in supporting the growth of heterotrophic bacteria (Chen et al. 2009; Porter et al. 2009). The uniqueness of caves is likely to account for a rich genetic potential and microbial diversity. However, the cave temperature, $\mathrm{CO}_{2}$ concentration and amount of water vapor increase in proportion to the number of tourists entering the cave and may cause changes in microclimatic conditions and food chain (Hoyos et al. 1998). Microbial diversity will also be affected as a result of these changes. High organic material input may lead to the disappearance of cave microorganisms by making the cave nonnative microorganisms more competitive than the cave inhabitants (Bastian \& Alabouvette 2009; Chelius et al. 2009; Mulec \& Kosi 2009; Fong 2011).

Culture methods were till recently used in most cave microbiology studies. However, as is well-known, culture-based methods being often inadequate in fully assessing the microbial diversity in a specific environment. Increasing use of molecular methods has led to a better understanding of cave diversity and cave ecosystem characteristics. The next generation sequencing technology enables much more microorganisms to be detected with high sensitivity at the DNA level and identifies non-cultured microorganisms. Such techniques shed light on current studies about caves in the field of biology and biotechnology.

$40 \%$ of the Turkey is covered with karstic carbonate and sulfate rocks. Because of that, this country has standing as the richest karst areas in European countries. Although there is still a significant number of undiscovered caves in Turkey, it is estimated based on research made in karstic areas that, around 35.000-40.000 caves may well be found spread all over the country (General Directorate of Mineral Research and Explorations 2020).

Our study aims to determine and compare the microbial diversity of the Dupnisa Cave regions, open to tourism as well as those which are closed; therefore, the community structure of bacteria and archaea in samples collected from the Kuru Cave and Sulu Cave regions of the cave is determined using the next generation Illumina MiSeq sequencing approach.

\section{CAVE DESCRIPTION}

Dupnisa Cave, located in Kurklareli-Sarpdere Village, the north-west of Turkey, is a horizontal cave system of $2720 \mathrm{~m}$ long (Paksuz 2017). This system comprises three interconnected caves, so-called Kuru Cave $\left(41^{\circ} 50^{\prime} 20^{\prime \prime} \mathrm{N}\right.$; $\left.27^{\circ} 33^{\prime} 26^{\prime \prime} \mathrm{E}\right)$, Sulu Cave (41 $\left.50^{\prime} 29^{\prime \prime} \mathrm{N} ; 27^{\circ} 33^{\prime} 25^{\prime \prime} \mathrm{E}\right)$ and $\mathrm{Kuz}$ Cave $\left(41^{\circ} 50^{\prime} 07^{\prime \prime} \mathrm{N} ; 27^{\circ} 33^{\prime} 28^{\prime \prime} \mathrm{E}\right)$, which hydrologically contains fossil zones, semi-active and active zones (Fig. 1) (Nazik et al. 1998; Paksuz et al. 2007; Paksuz 2017). Dupnisa Cave System was opened to visit in 2003. Since then, it has been visited by nearly 35,000 visitors each year. First $200 \mathrm{~m}$ of Sulu Cave and $230 \mathrm{~m}$ of Kuru Cave contain walkways and lighting used by tourists. However, $\mathrm{Kiz}$ Cave is fully closed to visitors. On the other hand, for the protection of hibernating bats and their secure reproduction, the Sulu Cave is closed to visitors only between November $15^{\text {th }}$ and May $15^{\text {th }}$ (Paksuz 2017; Nazik et al. 1998).
Dupnisa Cave has been evolved due to breakage of Pliocene relief system by quaternary streams and it possesses a polycyclic growth character (Nazik et al. 1998). Kuru and Kiz Caves at the top have completely become fossilized. Sulu Cave, at the bottom, is the longest one $(1977 \mathrm{~m})$ and has an active structure in which cave formation is still progressing. It has lakes up to $2 \mathrm{~m}$ in depth and a large underground stream with continuous flow. Kızılc1k Stream, originating from mountains at the south, comes back to the surface after passing through Sulu Cave (Nazik et al. 1998). The most of organic material entering the Dupnisa Cave is provided by the guanos of 18 bat species living in it (Paksuz 2017) and the river flowing through the cave. In addition, artificial lighting at the entrance and touristic part of Dupnisa Cave supports the development of phototrophic microorganisms. 


\section{MATERIALS AND METHODS}

\section{SAMPLING SITE}

A total of 5 cave sediment samples were taken from Sulu and Kuru Caves which are parts of the Dupnisa Cave System in November 2015. Two of these samples were collected from a tourist area of Kuru Cave (F1 cave sediment sample; F2 cave sediment sample), while the other three ones were from Sulu Cave. One of the samples collected from the Sulu Cave was from the entrance (AF cave sediment sample) which is a touristic area (Fig. 1). The two other ones were collected from the dark zone, a nontourist area (A1 cave sediment sample; A2 cave sediment sample) (Fig. 1).

\section{PHYSICOCHEMICAL PROPERTIES OF THE ENVIRONMENT}

The physicochemical properties of the studied environment have been determined through the water stream from where A1 and AF samples have been collected. Two aliquots of water collected from A1 and AF areas in the cave were measured in situ in terms of temperature, $\mathrm{pH}$, dissolved oxygen, conductivity and total dissolved solids (TDS) using a portable multiparameter tool (a Hach Lange HQ40D multimeter). Air temperatures and humidity at the five investigation sites were measured by a portable Temperature/Humidity Meter (TFA 31.1O28).

\section{DNA ISOLATION}

The DNA was extracted from $0.3 \mathrm{~g}$ (wet weight) of cave sediment samples by using FastDNA SPIN Kit for Soil (MP Biomedical, Santa Ana, CA, USA) following the manufacturer's instructions.

\section{S RRNA METAGENOMIC SEQUENCING} LIBRARY PREPARATION AND SEQUENCING Isolated genomic DNAs were used for two-step PCRs in order to prepare 16S rRNA gene amplicon libraries. Each sample was subjected for two library preparations, archaeal and bacterial. Archaeal V4-V5 (Arch519F (5'-CAGCCGCCGCGGTAA-3') / Arch 915R (5'-GTGCTCCCCCGCCAATTCCT-3') regions and bacterial V3-V4 (341F: 5'-CCTACGGGNGGCWGCAG-3' / 805R: 5'- GACTACHVGGGTATCTAATCC-3) regions of $16 \mathrm{~S}$ rRNA gene were targeted for amplicon sequencing.

The protocol includes the primer pair sequences for the targeted regions of the $16 \mathrm{~S}$ rRNA. It also includes overhang adapter sequences appended to the primer pair sequences for the compatibility with the Illumina index and sequencing adapters. By using BiospeedyTM Proof Reading DNA Polymerase, 2x Reaction Mix (Bioeksen Ltd Co., Turkey) and $200 \mathrm{~nm}$ of each primer, the first PCR was realized on Biorad CFX Connect Instrument (Bio-Rad Laboratories, U.S.A.) under this program: 95 ${ }^{\circ} \mathrm{C}$ for 3 minutes, 25 cycles of $\left(95^{\circ} \mathrm{C}\right.$ for 30 seconds, 55 ${ }^{\circ} \mathrm{C}$ for 30 seconds and $72{ }^{\circ} \mathrm{C}$ for 30 seconds); $72{ }^{\circ} \mathrm{C}$ for 5 minutes. To verify the size ( $550 \mathrm{bp})$, the PCR product was run on an agarose gel, then purified by using BiospeedyTM PCR Product Purification Kit (Bioeksen Ltd. Co., Turkey).

The dual indices and Illumina sequencing adapters were attached to the purified first PCR products via the second PCR, which was run using the Nextera XT Index Kit (Illumina Inc., USA) with the following program: 95

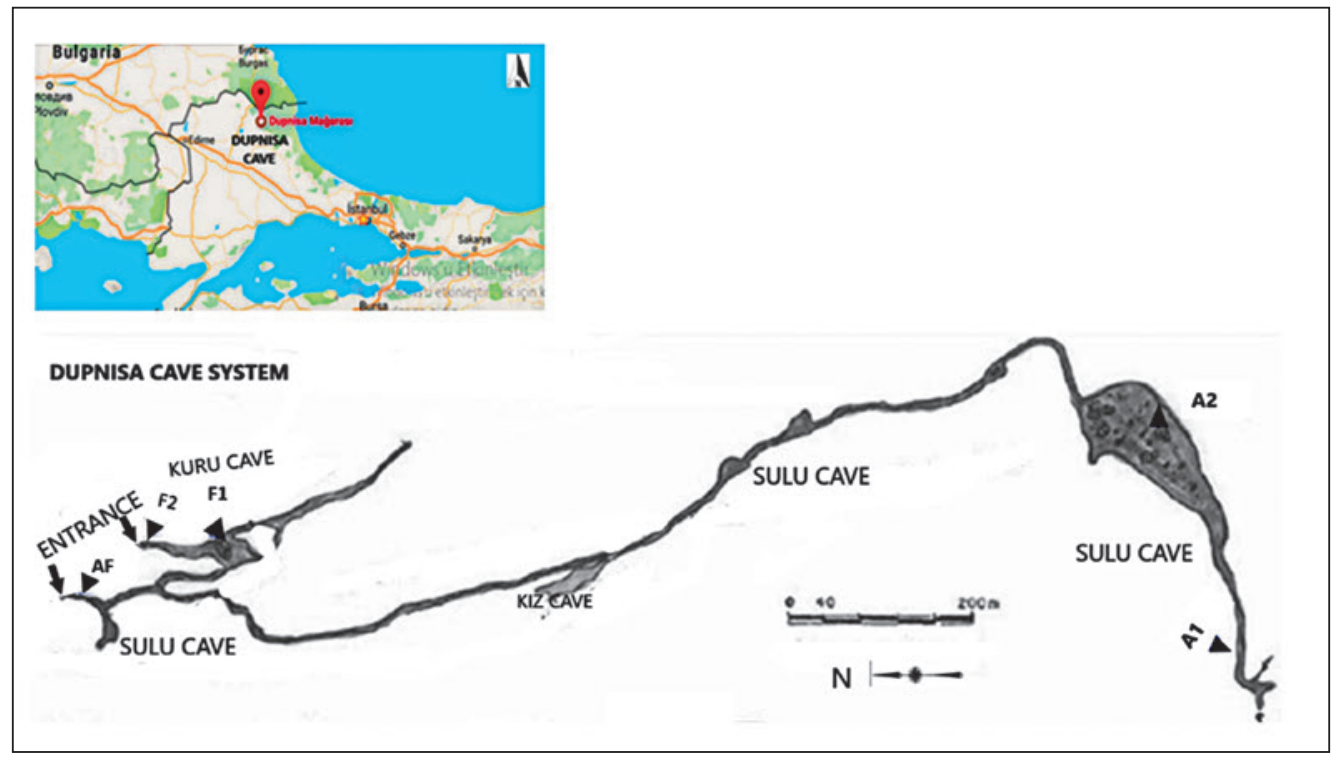

Fig. 1: The Dupnisa Cave System located in Turkey and sampling points (Adapted from Nazik et al. 1998). 
${ }^{\circ} \mathrm{C}$ for $3 \mathrm{~min}, 8$ cycles of $\left(95^{\circ} \mathrm{C}\right.$ for $30 \mathrm{~s}, 55^{\circ} \mathrm{C}$ for $30 \mathrm{~s}$, $72{ }^{\circ} \mathrm{C}$ for $30 \mathrm{~s}$ ) and $72{ }^{\circ} \mathrm{C}$ for $5 \mathrm{~min}$. The PCR products were purified using a Biospeedy ${ }^{\circledast}$ PCR Product Purification Kit. The final library was run on a Bioanalyzer DNA 1000 chip to verify the size ( $630 \mathrm{bp})$. The final library was diluted by using $10 \mathrm{mM}$ Tris ( $\mathrm{pH} 8.5$ ) to $4 \mathrm{nM}$ and the $5 \mathrm{~mL}$ aliquots were mixed for pooling the libraries. In preparation for the cluster generation and sequencing, pooled libraries were denatured with $\mathrm{NaOH}$, diluted with hybridization buffer (HT1), and then heat denatured before the MiSeq sequencing. Illumina MiSeq v3 reagent kits were used for the runs.

\section{BIOINFORMATIC ANALYSIS}

Following the Mothur Version 1.36.1, the raw sequence data (concatenated forward and reverse sequence reads) were cleaned, reduced and analysed. First, the barcode and the primer sequences were trimmed in order to identify unique sequences. Then, using BLASTn algorithm (Pruesse et al. 2007) this unique sequences were aligned to the SILVA rRNA database sequences. Bacterial and archaeal 16S rRNA gene amplicon data were analysed separately. The extending at the ends was putted out by filtering the sequences, then the redundancy check was carried out. The sequences were pre-clustered in order to further de-nosing. By utilizing the implanted code UCHIME (Edgar et al. 2011) the chimeras were excluded. The sequences were classified by using Bayesian classifier implanted in Mothur. The reference and taxonomy files were chosen from the SILVA database (Pruesse et al. 2007). After Operational Taxonomic Unit (OTU) picking and their taxonomic assignment using the SILVA rDNA database, the OTUs were binned into phylotypes. Additionally, the microbial diversity was analysed within the sample by calculating Shannon and Chaol. Chao was used to determine community richness, and Shannon index was used to determine community diversity.

\section{SEQUENCE ACCESSION NUMBERS}

The raw sequencing data generated in this study were deposited into the NCBI database under the accession numbers SAMN08142743, SAMN08142744, SAMN08142745, SAMN08142746 and SAMN08142747.

\section{RESULTS}

\section{PHYSICOCHEMICAL ANALYSIS}

The cave sediment samples taken from five designated sites of the Dupnisa Cave were analysed. The air temperatures and humidity values of the five investigation sites are shown in Tab. 1. In addition, physicochemical analysis of the waters where the cave sediment samples were taken are shown in Tab. 2 .

\section{BACTERIAL TAXONOMY AND DISTRIBUTION}

The bacterial diversity of the Dupnisa Cave has been investigated at five different sampling locations. All the sequence reads were assigned into 1109 OTUs (based on 97 $\%$ cutoff) at the genus level of the taxonomy. The bacterial OTUs can be assigned into 14 phyla, 64 orders, 130 families and 298 genera. The bacterial diversity in the sam-

Tab. 1: Sampling sites, air temperature and humidity.

\begin{tabular}{|l|c|c|c|c|c|}
\hline Sampling Location & Cave & Abbreviation & Parts & $\begin{array}{c}\text { Air } \\
\text { temperature }{ }^{\circ} \mathbf{C}\end{array}$ & $\begin{array}{c}\text { Air } \\
\text { humidity } \%\end{array}$ \\
\hline Water spring & Sulu & A1 & Active & 13.1 & $78 \%$ \\
\hline Last gallery & Sulu & A2 & Active & 12.6 & $95 \%$ \\
\hline Touristic area 1 & Kuru & F1 & Fossil & 15.2 & $81 \%$ \\
\hline Touristic area 2 & Kuru & F2 & Fossil & 14.9 & $79 \%$ \\
\hline Cave entrance & Sulu & AF & Active & 10.6 & $71 \%$ \\
\hline
\end{tabular}

Tab. 2: Physicochemical parameters from water samples.

\begin{tabular}{|l|c|c|c|c|c|}
\hline Water Samples Location & $\begin{array}{c}\text { Water } \\
\text { temperature }{ }^{\circ} \mathbf{C}\end{array}$ & $\mathbf{p H}$ & $\begin{array}{c}\text { Conductivity } \\
(\boldsymbol{\mu s} / \mathbf{c m})\end{array}$ & $\begin{array}{c}\text { TDS } \\
(\mathbf{m g} / \mathbf{L})\end{array}$ & $\begin{array}{c}\mathbf{O 2} \\
(\mathbf{m g} / \mathbf{L})\end{array}$ \\
\hline Water spring (A1) & 12.2 & 8.7 & 290 & 178 & 10.2 \\
\hline Cave entrance (AF) & 9.8 & 8.5 & 255 & 156 & 10.3 \\
\hline
\end{tabular}


ples taken from the active and fossil parts of the Dupnisa Cave System was found to be quite different. The highest diversity was observed on F2 and AF samples (Fig. 2).

Only eight phyla, Actinobacteria, Proteobacteria, Acidobacteria, Firmicutes, Bacteroidetes, Nitrospirae, Chloroflexi, and Gemmatimonadetes, containing more than $98 \%$ of the total sequence read, show mean abundance more than $1 \%$ in at least one sample holding more than $98 \%$ of the total sequence reads. For Actinobacteria and Proteobacteria, the abundance rate in all sampling locations is above $1 \%$. The most dominant phylum both in the active and fossil region of cave is Proteobacteria except in A2 area (Fig. 2). The most predominant phylum in A2 was observed to be Bacteroidetes (64.2\%). Yet, in the other sampling regions, Bacteroidetes remain below $1 \%$. Besides, Chloroflexi and Nitrospirae phyla remain

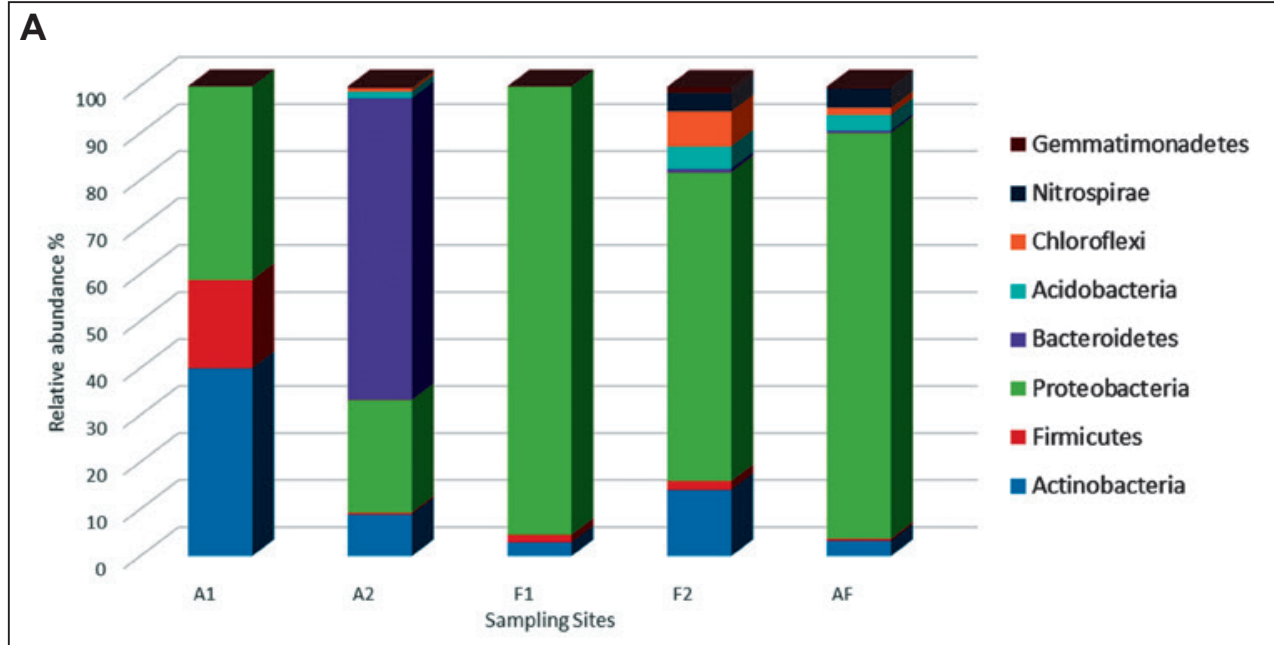

B

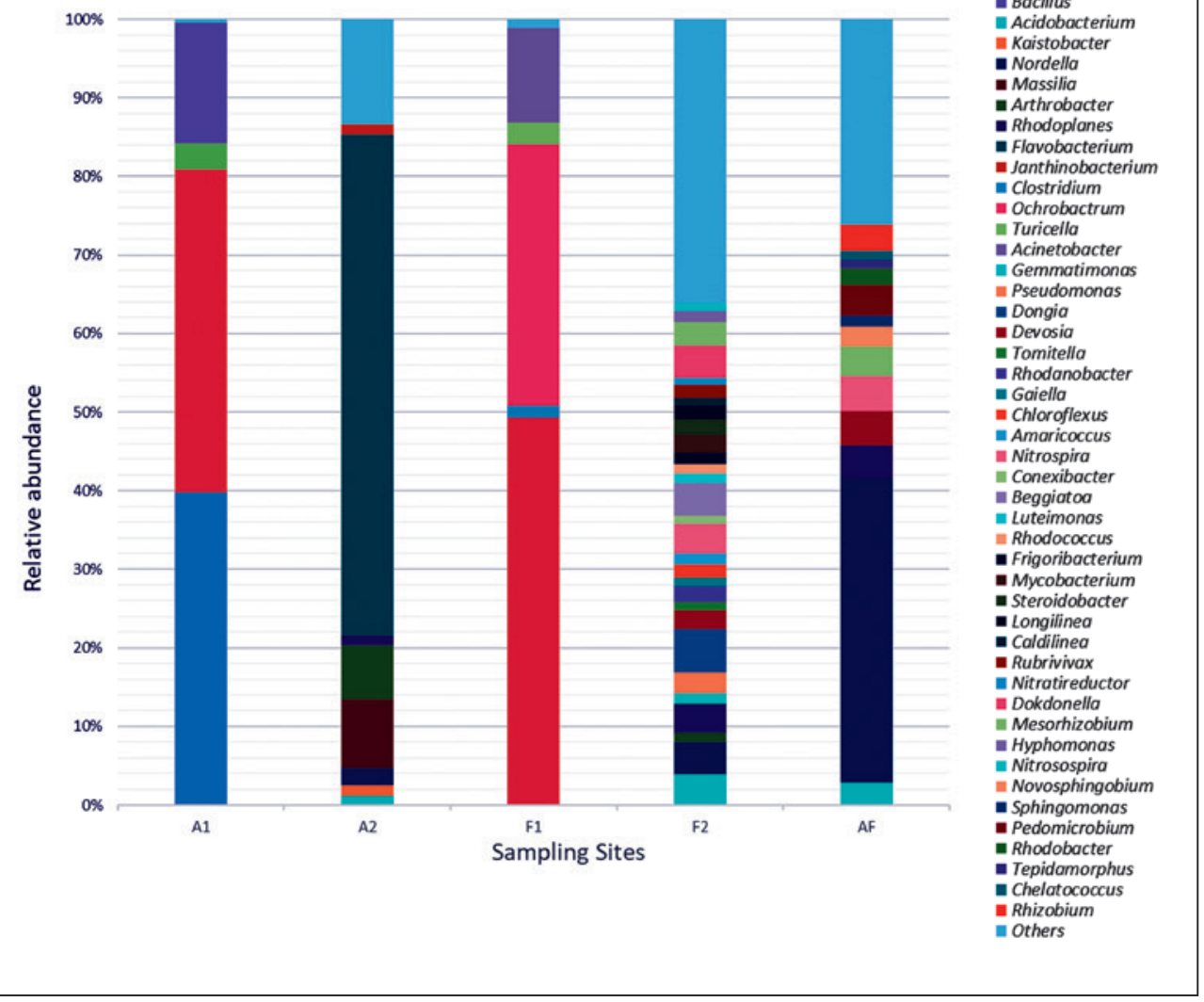

Fig. 2: Relative abundance of the bacterial community at the phylum (A) and genus (B) level. Samples sites; $A 1$ (Water spring), A2 (Last gallery), F1 (Touristic area 1), F2 (Touristic area 2), AF (Cave entrance). 
above $1 \%$ abundance rate at $\mathrm{F} 2$ and AF sampling points, and Gemmatimonadetes is above $1 \%$ only at F2 sampling point.

At the class level, Alpha-Proteobacteria and Actinobacteria were present at all sample areas. Alpha-Proteobacteria was the dominant class of phylum Proteobacteria, ranging from 10.6-83.2 \% within the samples, compared to other Proteobacteria classes; Beta-Proteobacteria (0.04-11\%), Gamma-Proteobacteria (0.03-18 $\%)$ and Delta-Proteobacteria (0.02-1.5\%). Except for the second active area (A2), Alpha-Proteobacteria was found to be the most dominant class in both fossil and active areas.

Among the Alpha-Proteobacteria, Nordella (35.5\% at AF), Ochrobactrum (33.2 \% at F1) and Methylobacterium ( $41 \%$ at $\mathrm{A} 1$ and $49.3 \%$ at $\mathrm{F} 1$ ) are observed as the most predominant genera. The bacteria which are found more abundant at F2 is Dongia (5.4 \%) which belongs to Alpha-Proteobacteria family. It is also observed that Gamma-Proteobacteria is more predominated in the fossil locations at F1 (12\%) and at F2 (18\%). While the Acinetobacter genus of Gamma-Proteobacteria is found predominantly at F1, the abundance of Dokdonella (4\%) and Beggiatoa (4.2\%) genera are highly expected at F2. The Beta-Proteobacteria is found in its highest rate at A2 and Massilia (8.8\%) is the most predominant genus observed. Actinobacteria class is found in range of 2.9-40 $\%$ with the most detected genera were Propiniobacterium (39.8\%) at A1 and Arthrobacter (6.8 \%) at A2. Flavobacterium genus (63.8\%), which belongs to Flavobacteriia class, is revealed to be the most predominating genus at A2.

In this study, a total of 130 families were obtained. 19 families Rhodocyclaceae, Hyphomicrobiaceae, Propionibacteriaceae, Rhizobiaceae, Bacillaceae, Flavobacteriaceae, Brucellaceae, Beijerinckiaceae, Methylobacteriaceae, etc., were commonly shared by all samples. There were 20 rare families that only appeared in one sample, such as Parvularculaceae, Legionellaceae, Dehalococcoidia, Paenibacillaceae, Streptosporangiaceae, Sanguibacteraceae, Chloroflexi, etc., that were found $(<1 \%)$ in samples except Corynebacterineae (>1\%).

The most genera were determined in AF point (208 genera) while the fewest were found in A1 point (66 genera) (Tab. 3). Shannon diversity index (to measure diversity by taking into account the number of genera/species as well as their abundance) for bacteria shows that, F2 had the highest diversity (Shannon $=5.61$ ), which was much larger than the diversity of A1 (Shannon $=1.20$ ) among the five communities (Tab. 4). Chaol index (estimation of total genus/species richness) for bacteria, indicates that $\mathrm{AF}$ had the highest bacterial richness (Chao = 768), while A1 had the lowest (Chao = 306).
Tab. 3: Number of bacterial and archaeal genus at the sample points.

\begin{tabular}{|l|c|c|c|c|c|}
\multicolumn{1}{c}{} & \multicolumn{1}{c}{ A1 } & A2 & F1 & F2 & \multicolumn{1}{c|}{ AF } \\
\hline Number of genus (All) B & 66 & 190 & 74 & 188 & 208 \\
\hline $\begin{array}{l}\text { Number of genus } \\
(>1 \%) \text { B }\end{array}$ & 4 & 9 & 5 & 29 & 16 \\
\hline Number of genus (All) A & 9 & 9 & 9 & 19 & 12 \\
\hline $\begin{array}{l}\text { Number of genus } \\
(>1 \%) \text { A }\end{array}$ & 9 & 6 & 9 & 7 & 9 \\
\hline
\end{tabular}

B: Bacteria; A: Archaea

Tab. 4. Characteristics of cave bacteria richness and diversity indices among different sample points of Dupnisa Cave.

\begin{tabular}{|l|c|c|c|c|c|}
\multicolumn{1}{c}{} & \multicolumn{1}{c}{ A1 } & F1 & A2 & F2 & AF \\
\hline $\begin{array}{l}\text { Shannon-Wiener } \\
\text { Diversity Index (Bacteria) }\end{array}$ & 1.20 & 1.34 & 3.68 & 5.61 & 4.97 \\
\hline $\begin{array}{l}\text { Chao1 Richness } \\
\text { Estimation (Bacteria) }\end{array}$ & 306 & 709 & 721 & 681 & 768 \\
\hline
\end{tabular}

\section{ARCHAEAL TAXONOMY AND DISTRIBUTION}

A total of 118 OTUs (based on $97 \%$ cutoff) comprising 2 archaeal phyla were detected in this study. Abundance rate of Euryarchaeota in the samples taken from the active and fossil parts of the Dupnisa Cave System was found between $8.2 \%-16 \%$, whereas that of Thaumarchaeota was between $84 \%-91.8 \%$. The archaeal OTUs can be assigned into 11 orders, 14 families and 20 genera (Fig. 3).

Thaumarchaeota class from Thaumarchaeota phylum and Methanomicrobia class from Euryarchaeota phylum were determined above $1 \%$ at all sampling points. However, Methanobacteria and Methanococci class members exceeded $1 \%$ abundance rate only at $\mathrm{A} 1$, F1, and F2 sampling points. Nitrososphaeraceae, Cenarchaeaceae, Nitrosopumilaceae are the families which has $5 \%$ over all the samples taken from the active and fossil parts of the Dupnisa Cave System. Nitrososphaeraceae was determined as the most dominating group in all samples (58.5-68.8\%), except at the AF point. The highest number of archaeal genera was determined at F2 (Tab. 3). Abundances of Candidatus Nitrososphaera and Nitrososphaera archaeal genera at A1, A2, F1 and F2 points were between $30.5-43.8 \%$ and $25-28.7 \%$, respectively, whereas, they were $10.9 \%$ and $2.3 \%$ respectively at $\mathrm{AF}$ point. The most dominating genus at $\mathrm{AF}$ was $\mathrm{Ce}$ narchaeum (49\%). Besides, Thermococcus (4.5\%), Thermoplasma (3.3\%) and Thermogymnomonas (3.2\%) genera were only determined at AF samples. Abundance of Nitrosopumilus at A2 (4.4\%) was much lower than those measured at the other studying sites (12.5-19.8\%). On the other hand, Candidatus Nitrosotalea and Methanosaeta were the most abundant at the A2 site with $15.6 \%$ 
and $15.4 \%$, respectively. However, Candidatus Nitrosotalea was not detected at the other points, while Methanosaeta was observed between $1.5-3.1 \%$ at these points.

Tab. 5: Characteristics of cave archaea richness and diversity indices among different sample points of Dupnisa Cave.

\begin{tabular}{|l|c|c|c|c|c|}
\multicolumn{1}{c}{} & \multicolumn{1}{c}{ A1 } & F1 & A2 & F2 & AF \\
\hline $\begin{array}{l}\text { Shannon-Wiener } \\
\text { Diversity Index } \\
\text { (Archaea) }\end{array}$ & 2.64 & 2.20 & 2.49 & 2.66 & 2.14 \\
\hline $\begin{array}{l}\text { Chao1 Richness } \\
\text { Estimation (Archaea) }\end{array}$ & 106 & 43 & 34 & 111 & 57 \\
\hline
\end{tabular}

The most genera were determined in F2 point (19 genera). Chaol index (estimation of total genus/species richness) for archaea indicates that the F2 sample had also the highest richness $($ Chao $=111)$, followed by A1 $($ Chao $=106)$, and the lowest one $($ Chao $=34)$ was observed at A2. Shannon diversity index (to measure diversity by taking into account the number of genera/species as well as their abundance) for archaea shows that, F2 had the highest diversity (Shannon $=2.66$ ) followed closely by A1 whereas AF had the lowest one (Shannon = 2.14) (Tab. 5).

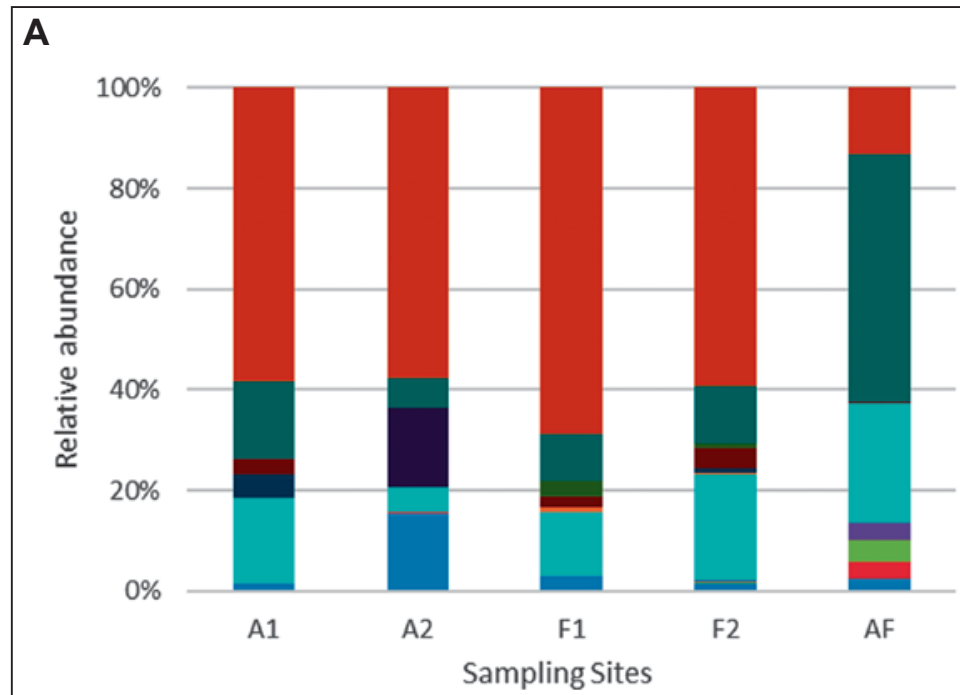

- Methanosaetaceae

- Thermoplasmatales

- Thermococcaceae

- Thermoplasmataceae

- Nitrosopumilaceae

nethanothermaceae

- Methanobacteriaceae

- Methanococcaceae

- Methanocaldococcaceae

- Thaumarchaeota

- Cenarchaeaceae

- Nitrososphaeraceae

\section{B}

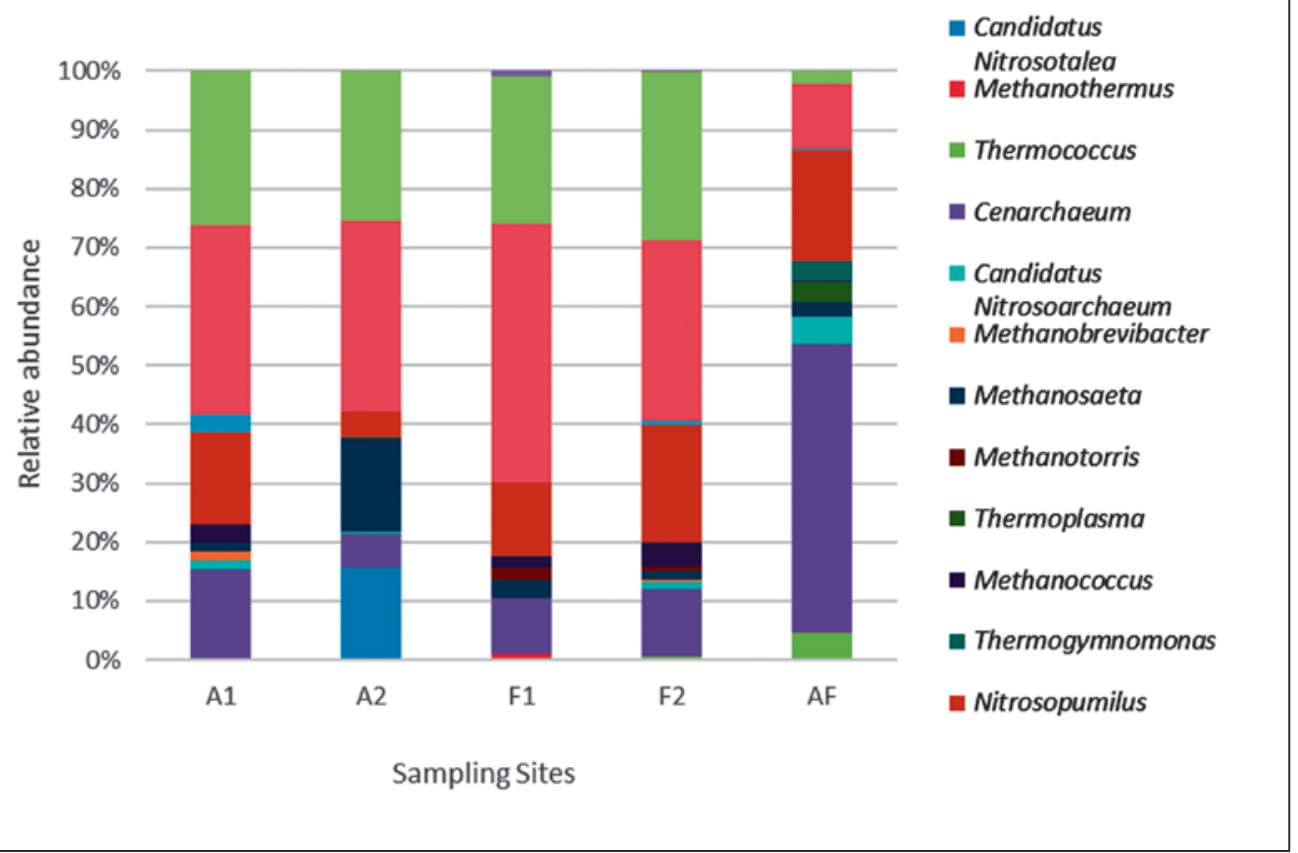

Fig. 3: Relative abundance of the archaeal community at the family (A) and genus (B) level. Samples sites; A1 (Water spring), A2 (Last gallery), F1(Touristic area 1), F2 (Touristic area 2), AF (Cave entrance). 


\section{DISCUSSION}

In this study we investigated the microbiome of the Dupnisa Cave, Kirklareli, Turkey by Illumina. Paksuz et al. (2007) stated that the humidity in the Dupnisa Cave System varied between $57 \%$ and $100 \%$ and found that the Sulu Cave humidity was higher than the Kuru Cave one. In addition, Paksuz et al. (2007) reported that in Sulu Cave, the average temperature in winter is $7.4^{\circ} \mathrm{C}$ and in summer $10.7^{\circ} \mathrm{C}$ while in Kuru Cave in winter it is $11.4^{\circ} \mathrm{C}$ and in summer it is $16.3^{\circ} \mathrm{C}$. According the physicochemical characteristics of caves in general, Dupnisa Cave ecosystem is a typical example of most cave systems with high relative humidity and limited temperature changes due to its connection with the surface (Paksuz 2017). It was determined that the $\mathrm{pH}, \mathrm{O}_{2}$, conductivity and TDS values of the waters dripping over the cave were very similar at points A1 and AF. Conductivity is an indirect measurement of salinity and total dissolved solids (TDS) content (Al Dahaan et al. 2016). These details highlight the similarity in chemical environment existing within the cave areas.

Culture-based techniques are known to release only 0.1-1\% of the total microorganisms (Torsvik \& Øvreas 2002). With the development of molecular methods, microbial diversity studies have also gained a new breath. Next Generation Sequencing (NGS) is one of these methods. Illumina, which is one of the NGS platforms used in our study, has important advantages such as having relatively cheap price per base and high sorting depth despite short length readings (Van Dijk et al. 2014). In culture-based studies, it was determined that cave isolated bacteria belong mostly to Proteobacteria, Actinobacteria, Bacteroidetes and Firmucutes groups (Barton \& Jurado 2007; Zhou et al. 2007; Jurado et al. 2010; Barton 2015), while in non-culture based studies, groups such as Acidobacteria, Planctomycetes, Chloroflexi, Bacteroidetes, Gemmatimonadetes, Firmicutes, Nitrospirae and Actinobacteria have been identified (Chelius \& Moore 2004; Zhou et al. 2007; Lee et al. 2012; Oliveira et al. 2017; Lavoie et al. 2017). In our study, Proteobacteria, Actinobacteria, Bacteroidetes, Gemmatimonadetes, Firmicutes, Nitrospirae, Chloroflexi and Acidobacteria phyla (1\% and above) were also observed. De Mandal et al. (2015) and De Leon et al. (2018) have also identified Proteobacteria, Chloroflexi, Actinobacteria, Bacteroidetes, Firmucutes and Planctomycetes phyla in bat guanos.

Proteobacteria phylum, having a key role in biogeochemical cycles, and being abundant in samples from cave sediment, soil, dripping water and cave surface is a cosmopolitan bacterial group (Zhou et al. 2007; Tomczyk-Zak \& Zielenkiewicz 2016). It was also found to be the most common and abundant phylum in cave sedi- ment samples taken from Dupnisa Cave. It is estimated that this phylum members involved in many biochemical processes in oligotrophic environments, may be primary producers in cave communities (Tomczyk-Zak \& Zielenkiewicz 2016). The composition and proportions of Proteobacteria population were found to be high in caves having interactions with humans, especially in those open to tourism (Northup et al. 2003; Ikner et al. 2007; Bastian \& Alabouvette 2009; Shapiro \& Pringle 2010). The most dominant class in the Proteobacteria in Dupnisa Cave is Alpha-Proteobacteria, except at the point A2. Methylobacterium, the most dominant genus in A1 and F1, which can use a wide range of carbon substrates, perform Type I formaldehyde assimilation and can be found in various media, have been determined in caves in previous studies (Barton et al. 2004; Ilkner 2007). In addition, the second dominant Proteobacteria group identified in our study is Gamma-Proteobacteria similar to the results observed in some previous study (Chen et al. 2009; Jones et al. 2010). It was suggested that Acinetobacter, which was found to have the highest rate $(12 \%)$ at F1, mobilized inorganic phosphate and could provide us important information about feeding in nutrient-limited cave ecosystems (Tomczyk-Zak \& Zielenkiewicz 2016). The Gamma-Proteobacteria class is known to contain various metabolically and ecologically chemolithotrophs which can use various inorganic molecules as the electron source (Tomczyk-Zak \& Zielenkiewicz 2016). Thereby, they might play a vital role in sustaining diverse groups of other microorganisms in this ecosystem. Barton et al. (2007) reported, similarly with our result, that the most abundant genus in the Carlsbad Cave (USA) is Massilia belonging to the Beta-Proteobacteria group. Members of this genus produce acid by using carbon-carbohydrates and organic compounds as carbon and energy sources (Kersters 2006). This acid, which is corrosive to calcite, can play a role in the structural change of caves.

Actinobacteria, the second dominant group in the Dupnisa Cave, is one of the most dominant and widespread phyla in the caves. Studies have shown that this phylum is found in cave walls, soil, sediment and speleothem surfaces and it has been suggested that it can play an important role in the formation of biomineralization and cave structures in the cave ecosystem (Pašić et al. 2010; Cuezva et al. 2012; Ortiz et al. 2013; Tomczyk-Zak \& Zielenkiewicz 2016). Arthrobacter genera, which was found in the percentage of $6.8 \%$ at point $A 2$, is interpreted to be responsible from the mineralization of calcite by the studies carried out (Rusznyák et al. 2012; Baskar et al. 2018).

According to research conducted by the Human 
Microbiome Project Consortium (2012), we considered the following genera might be related of human origin: Lactobacillus, Propionibacterium, Streptococcus, Bacteroides, Corynebacterium, Staphylococcus, Moraxella, Haemophilus, Prevotella and Veillonella. Propionibacterium has been observed at high rate in only the sample point A1 which is not open for tourism and thought to have no human impacts. Although the studies have been associated with human contamination (contamination during sampling or at the areas with human interaction), no other bacteria related with human contamination such as Streptococcus and Staphylococcus were identified. In addition, the river flowing through Dupnisa Cave can reduce both human influences and carry organic matter from the outside into the cave. Further studies on this subject will have an important place in revealing this point.

The effect of most microbial communities detected in the cave has not been revealed yet on the ecology of the cave. It has been reported that Acidobacteria, Gemmatimonadetes, Nitrospirae, Chloroflexi phyla, which constitute a small percentage of the microbial community of the Dupnisa Cave, are important members of the cave ecosystems (Schabereiter-Gurtner et al. 2002; Pašić et al. 2010; Rusznyak et al. 2012; Hathaway et al. 2014; Wiseschart et al. 2018). Some members of Acidobacteria, which is found at small percentages in the caves, has methylotrophic growth ability and has an ecological advantage in an oligotrophic habitat with low organic matter input (Kalyuzhnaya et al. 2008). Chloroflexi phylum was detected over $1 \%$ in the samples taken from the cave entrance ( $1.5 \% \mathrm{AF})$ and tourist section $(7.5 \% \mathrm{~F} 2)$ of Dupnisa Cave. Although members of this group are known to play a role in bioremediation, their ecological role in the cave system has not been identified yet (Wu et al. 2019; Yan et al. 2019). Like Acidobacteria and Chloroflexi phyla, information about the potential metabolic functions of Bacteroidetes in caves is limited (Schabereiter-Gurtner et al. 2002; Chelius \& Moore 2004; Macalady et al. 2006; Ikner et al. 2007; Rusznyák et al. 2012). As in Carlsbad Cavern and Krubera-Voronja Abkhazia, Georgia caves, the genus Flavobacterium was identified at the point A2 of Dupnisa Cave (Griffin et al. 2014; KieraiteAleksandrova et al. 2015). It has been reported to be active in the formation of ferromanganese deposits with their capacity to oxidize Mn (II) (Carmichael et al. 2013). Nitrospira genus which is a member of Nitrospirae and which was found in the percentage of 3.8 and $4.1 \%$ at F2 and AF points respectively, is nitrite oxidizing bacteria which can convert ammonia $\left(\mathrm{NH}_{3}\right)$ to nitrite $\left(\mathrm{NO}_{2}\right)$. Members of this bacteria have been detected in many caves such as Pajsarjeva Jama Cave, Slovenia, Oylat Cave, Turkey and Tito Bustillo Cave, Spain (Schabereiter-Gurtner et al. 2002; Pašić et al. 2010; Gulecal-Pektas 2016).
They support primary production by oxidizing the nitrite in caves (Ortiz et al. 2013).

It is evaluated that archaeal communities have important roles in cave ecosystems and the existence of Euryarchaeota, Crenarchaeota, Korarchaeota, Thaumarchaeota and some candidate phylum was observed in caves. However, the information obtained from the studies is still limited (Engel 2010; Carmichael et al. 2013; Jones et al. 2014; Kieraite-Aleksandrova et al. 2015). Only the phylum Thaumarchaeota and Euryarchaeota were identified in the Dupnisa Cave. The newly discovered Thaumarchaeota is known to be a chemoautotrophic ammonia oxidizer and is remarkable for its ability to developing in oligotrophic environments such as caves (Martens-Habbena et al. 2009; Pester et al. 2011; Ortiz et al. 2014; Kimble 2017; Zhao et al. 2017). In caves, ammonia from organic matter mineralization and / or guano deposits may be an energy source for chemolithotrophic organisms (Hathaway et al. 2014). In fact, the archaeal community analysis of bat guano sampled in the Domica Cave showed that the archaeal ammonia oxidizers were dominant as it is in Dupnisa Cave samples (Chronakova et al. 2009). Furthermore, Thaumarchaeota (over 80 \%) was identified as the dominant archaeal phylum in the Dupnisa Cave, like in Kartchner Caverns (Arizona, USA) and Weebubbie Cave (Arizona, USA) (Bates et al. 2011; Tetu et al. 2013). Members of Thaumarchaeota are the dominant players in global nitrification (Stahl \&De la Torre 2012; Ortiz et al. 2014; Zhao et al. 2017). They could be important since the nitrogen cycle provides nutrients and energy for microorganisms in oligotrophic environments such as caves (Tetu et al. 2013; Ortiz et al. 2014; Kimble 2017; Zhao et al. 2017).

Ammonia oxidizing bacteria (AOB) and ammonia oxidizing archaea (AOA) are responsible for the microbial oxidation of ammonia (Bartossek et al. 2012; Stahl and De la Torre 2012; Ortiz et al. 2014). In our study, Nitrosopumilus, Nitrososphaera, Candidatus Nitrososphaera and Cenarchaeum were predominantly detected at all sampling points. It was reported that Nitrosopumilus is an ammonia oxidizing marine archaeon (member of group I) and Nitrososphaera is frequently found in terrestrial environments (Tetu et al. 2013; Ortiz et al. 2014). The results of studies held by Anda et al. (2017) in Molnár János Cave, Hungary showed an archaea diversity like those of the Dupnisa Cave. Only members of Thaumarchaeota and Euryarchaeota phyla were detected in this cave and it was reported that the percentage of Thaumarchaeota phylum was very high. The most abundant genus of Thaumarchaeota phylum found in Molnár János Cave are Candidatus Nitrososphaera and Nitrososphaera. Similarly, in Alpine caves, Nitrosopumilus and Candidatus Nitrososphaera have been identified 
as dominant genus (Reitschuler et al. 2016). It is suggested that these microorganisms can provide nitrogen, through ammonium oxidation, to the other Dupnisa Cave organisms. Consequently, they contribute to the nutrient cycle of the cave. In parallel with the results of our study, AOA were found to be more dominant than ammonia oxidizing bacteria in Heshang Cave and Weebubbie Cave in China (Tetu et al. 2013; Zhao et al. 2017). It was suggested that the high level of AOA results from the high substrate affinity that allows them to multiply at lower ammonia concentrations than other organisms (Martens-Habbena et al. 2009).

The other phylum belonging to the archaea found in the Dupnisa Cave is Euryarchaeota which is one of the dominant phyla of the cave ecosystem (Chelius \& Moore 2004; Chen et al. 2009; Engel et al. 2010; Yasir 2018; Wiseschart et al. 2018). Methanogens in the Euryarchaeota phylum are anaerobic microorganisms with a unique metabolism that produces methane as a metabolic by-product. Methanothermus, Methanobrevibacter, Methanosaeta, Methanotorris, Methanococcus, Methanobacterium, Methanochaldococcus genus, which are members of Euryarchaeota phylum observed in Dupnisa Cave System, were determined at different sample points at different rates. Ițcuş et al. (2016) found Methanobacterium genus in the ice sample from Scarisoara Ice Cave (Romania). Methanogens are widely distributed in hot, acidic, salty areas such as deep sea sediments, freshwater sediments, rice field soils, hot springs and gut systems (Sarmiento et al. 2011; Ciais et al. 2014). The identification of thermophilic Methanogens in the Dupnisa Cave part opened for tourism, may be due to the large number of bats in that cave.

It is also interesting to note that thermophiles such as the genus Thermococcus (4.5\%), Thermoplasma (3.3 $\%$ ) and Thermogymnomonas (3.2\%), which are also members of the Euryarchaeota phylum, are present in the mesophilic environment of the Dupnisa Cave at a rate of $3 \%$ or more at a single point. As observed in the AF sample of our sample, the genus Thermogymnomonas has been detected also in the Hundalm Cave in Tyrol
(Austria) (Reitschuler et al. 2014). Although the Thermoplasmata has been reported in other cave environments, their ecological role in these environments still unclear. Their presence in caves has been widely identified in the sulfide rich environments (Macalady et al. 2006; Jones et al. 2012; Jones et al. 2014; Gulecal-Pektas \& Temel 2017). However, Thermoplasmata-related 16S rRNA sequences have been recently observed in all moonmilk (Reitschuler et al. 2014; Reitschuler et al. 2015) and cave sediments on a dry stream bed (Zhao et al. 2017).

As a result of metagenomic analysis of the samples taken from different points, the variation in the genus level became clear even though the difference in phylum level was not significant. Each microenvironment reveals its own microbial profile. According to the Chao 1 richness estimation index, the highest bacterial richness was found at the AF point (Cave entrance / cave sediment) and the most archaeal types were at the F2 point (Touristic area 2 / cave sediment). The AF point is affected by daylight as well as bats and tourists. According to the Shannon-Wiener diversity index, the sampling point with the most abundant archaeal and bacterial genus was determined as F2.

Dupnisa Cave has a rich content in terms of bacterial and archaea variety. The river running through it, guanos and tourists that visit there could be the source of the organic material inputs of Dupnisa Cave. When the bacteria and archaea taxa, which were determined in our study and are found predominantly in all caves, are examined at the genus level, it is seen that even the different points of each cave do not resemble each other. The diversity of bacteria and archaea revealed in the samples taken from the part open to tourism and the closed part of the Dupnisa Cave is a good example to prove it. Although the bacteria and archaea species detected in the Dupnisa Cave were found in other caves with different physicochemical properties, the communities formed by these genera and their percentages are different from each other and this is one of the most important factors that make the caves unique.

\section{CONCLUSIONS}

The caves are often difficult to be accessed but are ideal underground habitats for studying microbial metabolisms and microorganism relationships under oligotrophic conditions. Number of studies in microbiological diversity carried out in our days is increasing day by day, while the studies in this field were previously limited. Al- though the number of studies is increasing, each cave is unique in parallel with its features, and the studies continue to maintain their values. With this study, a molecular independent bacterial and archaeal profile work was performed for the first time in Dupnisa Cave. According to the obtained results, difference between cave parts, in 
term of microbial diversity, is revealed. Microbial biodiversity studies are important for us, since it provides new and different data which contribute to the world of microorganisms or this reason, the research of the Dupnisa Cave System is a guide for future studies.

Open or closed to tourism, our results show that the bacterial and archaeal communities in Dupnisa Cave are composed of niche-specific members rather than cosmopolitan. The high population of ammonia-oxidizing archaea $(\mathrm{AOA})$ discovered in our study suggests based on microbial diversity analysis that the ammonium oxidation could be one of the main energy sources in the Dupnisa Cave ecosystem. Our future studies will be aimed to enrich the biodiversity information and to determine the microorganisms with enzyme / antibiotic potential by adding samples from the walls of Dupnisa Cave System. This study is not a complete picture of the microbial diversity of the Dupnisa Cave. We believe that these findings and our next studies will contribute to reach the big picture.

\section{ACKNOWLEDGMENTS}

The author would like to thank the Anatolian Speleology Association for sampling. The authors also thank
Istanbul University Scientific Project Unit (BAP Project no 29244 and 42517) for their financial support.

\section{REFERENCES}

Anda, D., Krett, G., Makk, J., Márialigeti, K., MádlSzőnyi, J. \& A.K. Borsodi, 2017: Comparison of Bacterial and Archaeal communities from different habitats of the hypogenic Molnár János Cave of the Buda Thermal Karst System (Hungary).- Journal of Cave and Karst Studies, 79, 2, 113-121. https://doi. org/10.4311/2015MB0134

Barton, H.A., Taylor, M.R. \& N.R. Pace, 2004: Molecular phylogenetic analysis of a bacterial community in an oligotrophic cave environment.- Geomicrobiology Journal, 21, 1, 11-20. https://doi. org/10.1080/01490450490253428

Barton, H.A., 2006: Introduction to cave microbiology: a review for the non-specialist.- Journal of Cave and Karst Studies, 68, 2, 43-54.

Barton, H.A. \& V. Jurado, 2007: What's up down there? Microbial diversity in caves.- Microbe, 2, 132-138.

Barton, H.A., Taylor, N.M., Kreate, M.P., Springer, A.C., Oehrle, S.A. \& J.L. Bertog, 2007: The impact of host rock geochemistry on bacterial community structure in oligotrophic cave environments.- International Journal of Speleology, 36, 2, 93-104. http:// dx.doi.org/10.5038/1827-806X.36.2.5

Barton, H.A., 2015: Starving artists: Bacterial oligotrophic heterotrophy in caves.- In: Engel A. \& De Gruyter W. (eds.) Life in Extreme Environments: Microbial Life of Cave Systems. De Gruyter, pp. 350, New York.

Bartossek, R., Spang, A., Weidler, G., Lanzen, A. \& C. Schleper, 2012: Metagenomic analysis of ammonia- oxidizing archaea affiliated with the soil group.Frontiers in microbiology, 3, 208. https://doi. org/10.3389/fmicb.2012.00208

Baskar, S., Chalia, S. \& R. Baskar, 2018: Calcite precipitation by Rhodococcus sp. isolated from Kotumsar cave, Chhattisgarh, India.- Current Science, 114, 5, 1063-1074. https://doi.org/10.18520/cs/v114/ i05/1063-1074

Bastian, F. \& C. Alabouvette, 2009: Lights and shadows on the conservation of a rock art cave: the case of Lascaux Cave.- International Journal of Speleology, 38, 1, 55-60. http://dx.doi.org/10.5038/1827806X.38.1.6

Bates, S.T., Berg-Lyons, D., Caporaso J.G., Walters, W.A., Knight, R. \& N. Fierer, 2011: Examining the global distribution of dominant archaeal populations in soil.- The ISME journal, 5, 908-917. https://doi. org/10.1038/ismej.2010.171

Carmichael, M.J., Carmichael, S.K., Santelli, C.M., Strom, A. \& S.L. Bräuer, 2013: Mn (II)-oxidizing bacteria are abundant and environmentally relevant members of ferromanganese deposits in caves of the upper Tennessee River Basin.- Geomicrobiology Journal, 30, 9, 779-800. https://doi.org/10.1080/014904 51.2013 .769651

Chelius, M.K. \& J.C. Moore, 2004: Molecular phylogenetic analysis of Archaea and Bacteria in Wind Cave, South Dakota.- Geomicrobiology Journal, 21, 2, 123134. https://doi.org/10.1080/01490450490266389 
Chelius, M.K., Beresford, G., Horton, H., Quirk, M., Selby, G., Simpson, R.T., Horrocks, R. \& J.C. Moore, 2009: Impacts of alterations of organic inputs on the bacterial community within the sediments of Wind Cave, South Dakota, USA.- International Journal of Speleology, 38, 1-10. https://dx.doi. org/10.5038/1827-806X.38.1.1

Chen, Y., Wu, L., Boden, R., Hillebrand, A., Kumaresan, D., Moussard, H., Baciu, M., Lu, Y. \& J.C. Murrell, 2009: Life without light: microbial diversity and evidence of sulfur- and ammonium-based chemolithotrophy in Movile Cave.- The ISME Journal, 3, 1093 1104. https://doi.org/10.1038/ismej.2009.57

Chroňáková, A., Horák, A., Elhottová, D. \& V. Krištůfek, 2009: Diverse archaeal community of a bat guano pile in Domica Cave (Slovak Karst, Slovakia).- Folia microbiologica, 54, 5, 436-446. https://doi. org/10.1007/s12223-009-0061-2

Ciais, P., C. Sabine, G. Bala, L. Bopp, V. Brovkin, J. Canadell, A. Chhabra, R. DeFries, J. Galloway, M. Heimann, C. Jones, C. Le Quéré, R.B. Myneni, S. Piao \& P. Thornton, 2013: Carbon and Other Biogeochemical Cycles Supplementary Material.- In: Stocker, T.F. et al. (eds.) Climate Change 2013: The Physical Science Basis. Contribution of Working Group I to the Fifth Assessment Report of the Intergovernmental Panel on Climate Change. Cambridge University Press, pp. 465-570, Cambridge.

Cuezva, S., Fernandez-Cortes, A., Porca, E., Pašić, L., Jurado, V., Hernandez-Marine, M., Serrano-Ortiz, P., Hermosin, B., Cañaveras, J.C., Sanchez-Moral, S. \& C. Saiz-Jimenez, 2012: The biogeochemical role of actinobacteria in Altamira cave, Spain.- FEMS microbiology ecology, 81, 1, 281-290. https://doi. org/10.1111/j.1574-6941.2012.01391.x

De Mandal, S., Panda, A.K., Bisht, S.S. \& N.S. Kumar, 2015: First report of bacterial community from a bat guano using Illumina next-generation sequencing.Genomics Data, 4, 99-101. https://doi.org/10.1016/j. gdata.2015.04.001

De Leon, M.P., Montecillo, A.D., Pinili, D.S., Siringan, M.A.T. \& D.S. Park, 2018: Bacterial diversity of bat guano from Cabalyorisa Cave, Mabini, Pangasinan, Philippines: A first report on the metagenome of Philippine bat guano.- PloS one, 13, 10, e0200095. https://doi.org/10.1371/journal.pone.0200095

Edgar, R.C., Haas, B.J., Clemente, J.C., Quince, C. \& R. Knight, 2011: UCHIME improves sensitivity and speed of chimera detection.- Bioinformatics, 27, 16, 2194-2200. https://doi.org/10.1093/bioinformatics/ btr381

Engel, A.S., 2010: Microbial diversity of cave ecosystem.In: Loy A. et al. (eds.) Geomicrobiology: Molecular and environmental perspective. Springer Science and Business Media B.V., pp. 219-238, Dordrecht.

Engel, A.S., Meisinger, D.B., Porter, M.L., Payn, R.A., Schmid, M., Stern, L.A., Schleifer, K.H. \& N.M. Lee, 2010: Linking phylogenetic and functional diversity to nutrient spiraling in microbial mats from Lower Kane Cave (USA).- The ISME journal, 4, 98-110. https://doi.org/10.1038/ismej.2009.91

Fong, D.W., 2011: Management of subterranean fauna in karst.- In: Van Beynen P.E. (ed.) Karst management. Springer, pp. 201-224, Dordrecht..

General Directorate of Mineral Research And Explorations, 2020: Karst cave in Turkey and inventory.[Online] Available from: https://www.mta.gov.tr/ v3.0/arastirmalar/magara-envanteri [Accessed 3rd April 2020].

Griffin, D.W., Gray, M.A., Lyles, M.B. \& D.E. Northup, 2014: The transport of nonindigenous microorganisms into caves by human visitation: a case study at Carlsbad Caverns National Park.- Geomicrobiology Journal, 31, 3, 175-185. https://doi.org/10.1080/014 90451.2013.815294

Groth, I. \& C. Saiz-Jiménez, 1999: Actinomycetes in hypogean environments.- Geomicrobiology Journal, 16, 1, 1-8. https://doi.org/10.1080/014904599270703

Groth, I., Vettermann, R., Schuetze, B., Schumann, P. \& C. Saiz-Jiménez, 1999: Actinomycetes in karstic caves of Northern Spain (Altamira and Tito Bustillo).Journal of Microbiological Methods, 36, 1-2, 115 122. https://doi.org/10.1016/S0167-7012(99)000160

Gulecal-Pektas, Y., 2016: Bacterial diversity and composition in oylat cave (Turkey) with combined sanger/pyrosequencing approach.- Polish Journal of Microbiology, 65, 1, 69-75. https:77doi. org/10.5604/17331331.1197277

Gulecal-Pektas, Y. \& M. Temel, 2017: A Window to the Subsurface: Microbial Diversity in Hot Springs of a Sulfidic Cave (Kaklik, Turkey).- Geomicrobiology Journal, 34, 4, 374-384. https://doi.org/10.1080/014 90451.2016.1204374

Hathaway, J.J.M., Garcia, M.G., Balasch, M.M., Spilde, M.N., Stone, F.D., Dapkevicius, M.D.L.N.E., Amorim, I.R., Gabriel, Borges, P.A.V. \& D.E. Northup, 2014: Comparison of bacterial diversity in Azorean and Hawai'ian lava cave microbial mats.- Geomicrobiology journal, 31, 3, 205-220. https://doi.org/ 10.1080/01490451.2013.777491

Hoyos, M., Soler, V., Cañaveras, J.C., Sánchez-Moral, S. \& E. Sanz-Rubio, 1998: Microclimatic characterization of a karstic cave: human impact on microenvironmental parameters of a prehistoric rock art cave (Candamo Cave, northern Spain).- Environmental 
Geology, 33, 4, 231-242. https://doi.org/10.1007/ s002540050242

Ikner, L.A., Toomey, R.S., Nolan, G., Neilson, J.W., Pryor, B.M. \& R.M. Maier, 2007: Culturable microbial diversity and the impact of tourism in Kartchner Caverns, Arizona.- Microbial Ecology, 53, 30-42. https://doi.org/10.1007/s00248-006-9135-8

Ițcuş, C., Pascu, M.D., Brad, T., Perşoiu, A., \& C. Purcarea, 2016: Diversity of cultured bacteria from the perennial ice block of Scarisoara Ice Cave, Romania.International Journal of Speleology, 45, 1, 89-100. http://dx.doi.org/10.5038/1827-806X.45.1.1948

Jones, D.S., Tobler, D.J., Schaperdoth, I., Mainiero, M. \& J.L. Macalady, 2010: Community structure of subsurface biofilms in the thermal sulfidic caves of Acquasanta Terme, Italy.- Applied and Environmental Microbiology, 76, 17, 5902-5910. https://doi. org/10.1128/AEM.00647-10

Jones, D.S., Albrecht, H.L., Dawson, K.S., Schaperdoth, I., Freeman, K.H., Pi Y., Pearson, A. \& J.L. Macalady, 2012: Community genomic analysis of an extremely acidophilic sulfur-oxidizing biofilm.- The ISME Journal, 6, 158-170. https://doi.org/10.1038/ ismej.2011.75

Jones, A.A. \& P.C. Bennett, 2014: Mineral microniches control the diversity of subsurface microbial populations.- Geomicrobiology Journal, 31, 3, 246-261. https://doi.org/10.1080/01490451.2013.809174

Jurado, V., Laiz, L., Rodriguez-Nava, V., Boiron, P., Hermosin, H., Sanchez-Moral, S. \& C., Saiz-Jimenez, 2010: Pathogenic and opportunistic microorganisms in caves.- International Journal of Speleology, 39, 1, 15-24. http://dx.doi.org/10.5038/1827806X.39.1.2

Kalyuzhnaya, M.G., Lidstrom, M.E. \& L. Chistoserdova, 2008: Real-time detection of actively metabolizing microbes by redox sensing as applied to methylotroph populations in Lake Washington.- The ISME Journal, 2, 696-706. https://doi.org/10.1038/ismej. 2008.32

Kersters, K., De Vos, P., Gillis, M., Swings, J., Vandamme, P. \& E. Stackebrandt, 2006: Introduction to the Proteobacteria.- In: Dworkin, M. et al. (eds.) The Prokaryotes: a handbook on the biology of bacteria, 3rd Ed. Springer-Verlag, pp. 3-37, New York.

Kieraite-Aleksandrova, I., Aleksandrovas, V. \& N. Kuisiene, 2015: Down into the Earth: microbial diversity of the deepest cave of the world.- Biologia, 70, 8, 989-1002. https://doi.org/10.1515/biolog-2015-0127

Kimble, J.C., 2017: Comparison of Bacterial and Archaeal Communities in the Subsurface versus Surface: Impli- cations for Nitrogen Cycling.- $\mathrm{PhD}$ thesis. University of New Mexico, pp.152.

Lavoie, K.H., Winter, A.S., Read, K.J., Hughes, E.M., Spilde, M.N. \& D.E. Northup, 2017: Comparison of bacterial communities from lava cave microbial mats to overlying surface soils from Lava Beds $\mathrm{Na}$ tional Monument, USA.- PloS one, 12, 2, e0169339. https://doi.org/10.1371/journal.pone.0169339

Lee, I.T., Liu, J.Y., Lin, C.H., Oyama, K.-I., Chen, C.Y. \& C.H. Chen, 2012: Ionospheric plasma caves under the equatorial ionization anomaly.- Journal of Geophysical Research, 117, A11, A11309, https://doi. org/10.1029/2012JA017868

Macalady, J.L., Lyon, E.H., Koffman, B., Albertson, L.K., Meyer, K., Galdenzi, S. \& S. Mariani, 2006: Dominant microbial populations in limestone-corroding stream biofilms, Frasassi cave system, Italy.- Applied and Environmental Microbiology, 72, 8, 5596-5609. https://doi.org/10.1128/AEM.00715-06

Martens-Habbena, W., Berube, P.M., Urakawa, H., José, R. \& D.A. Stahl, 2009: Ammonia oxidation kinetics determine niche separation of nitrifying Archaea and Bacteria.- Nature, 461, 976-979. https://doi. org/10.1038/nature08465

Mulec, J. \& G. Kosi, 2009: Lampenflora algae and methods of growth control.- Journal of cave and karst studies, 71, 2, 109-115.

Nazik, L., Törk K., Özel, E., Mengi, H., Aksoy, B. \& C. Acar, 1998: Kuzey ve Kuzeydoğu Trakya’nın (Kırklareli-Tekirdağ) Doğal Mağaraları. Dosya No: 43584. Maden Tetkik ve Arama Genel Müdürlüğü, Jeoloji Etütleri Dairesi Başkanlığı, Ankara.

Northup D.E. \& K.H. Lavoie, 2001: Geomicrobiology of caves: a review.- Geomicrobiology Journal, 18, 3, 199222. https://doi.org/10.1080/01490450152467750

Northup, D.E., Barns, S.M., Yu, L.E., Spilde, M.N., Schelble, R.T., Dano, K.E., Crossey, L.J., Connolly, C.A., Boston, P.J., Natvig, D.O. \& C.N. Dahm, 2003: Diverse microbial communities inhabiting ferromanganese deposits in Lechuguilla and Spider Caves.Environmental Microbiology, 5, 11, 1071-1086. https://doi.org/10.1046/j.1462-2920.2003.00500.x

Oliveira, C., Gunderman, L., Coles, C.A., Lochmann, J., Parks, M., Ballard, E., Glazko, G., Rahmatallah, Y., Tackett, A.J. \& D.J. Thomas, 2017: 16S rRNA GeneBased Metagenomic Analysis of Ozark Cave Bacteria.- Diversity, 9, 3, 31. https://doi.org/10.3390/ d9030031

Ortiz, M., Neilson, J.W., Nelson, W.M., Legatzki, A., Byrne, A., Yu, Y., Wing, R.A., Soderlund, C.A., Pryor, B.M., Pierson, L.S. \& R.M. Maier, 2013: Profiling bacterial diversity and taxonomic composition on speleothem surfaces in Kartchner Caverns, 
AZ.- Microbial ecology, 65, 371-383. https://doi. org/10.1007/s00248-012-0143-6

Ortiz, M., Legatzki, A., Neilson, J.W., Fryslie, B., Nelson, W.M., Wing, R.A., Soderlund, C., Pryor, B.M. \& R.M. Maier, 2014: Making a living while starving in the dark: metagenomic insights into the energy dynamics of a carbonate cave.- The ISME Journal, 8, 478-491. https://doi.org/10.1038/ismej.2013.159

Palmer A.N., 1991: Origin and morphology of limestone caves.- Geological Society of America Bulletin, 103, 1, 1-21. https://doi.org/10.1130/00167606(1991)103<0001:OAMOLC > 2.3.CO;2

Paksuz, S., Özkan, B., \& T. Postawa, 2007: Seasonal changes of cave-dwelling bat fauna, and their relationship with microclimate in Dupnisa Cave System (Turkish Thrace).- Acta Zoologica CracoviensiaSeries A: Vertebrata, 50, 1-2, 57-66. https://doi. org/10.3409/000000007783995435

Paksuz, S., 2017: Important Caves in Turkish Thrace for Bats: Dupnisa Cave System and Koyunbaba Cave.In: S. Karabulut \& M. Cengiz (eds) Cave Investigation. IntechOpen, pp. 77-93, London.

Pašić, L., Kovče, B., Sket, B., \& B. Herzog-Velikonja, 2010: Diversity of microbial communities colonizing the walls of a Karstic cave in Slovenia.- FEMS Microbiology Ecology, 71, 1, 50-60. https://doi.org/10.1111/ j.1574-6941.2009.00789.x

Pester, M., Schleper, C., \& M. Wagner, 2011: The Thaumarchaeota: an emerging view of their phylogeny and ecophysiology.- Current opinion in $\mathrm{mi}-$ crobiology, 14, 3, 300-306. https://doi.org/10.1016/j. mib.2011.04.007

Porter, M.L., Engel, A.S., Kane, T.C. \& B.K. Kinkle, 2009: Productivity-diversity relationships from chemolithoautotrophically based sulfidic karst systems.International Journal of Speleology, 38, 1, 27-40. http://dx.doi.org/10.5038/1827-806X.38.1.4

Pruesse, E., Quast, C., Knittel, K., Fuchs, B.M., Ludwig, W., Peplies, J. \& F.O. Glöckner, 2007: SILVA: a comprehensive online resource for quality checked and aligned ribosomal RNA sequence data compatible with ARB.- Nucleic Acids Research, 35, 21, 71887196. https://doi.org/10.1093/nar/gkm864

Reitschuler, C., Lins, P., Wagner, A. O. \& P. Illmer, 2014: Cultivation of moonmilk-born non-extremophilic Thaum and Euryarchaeota in mixed culture.- Anaerobe, 29, 73-79. https://doi.org/10.1016/j.anaerobe.2013.10.002

Reitschuler, C., Lins, P., Schwarzenauer, T., Spötl, C., Wagner, A.O. \& P. Illmer, 2015: New undescribed lineages of non-extremophilic archaea form a homogeneous and dominant element within alpine moonmilk microbiomes.- Geomicrobiology Jour- nal, 32, 10, 90-902. https://doi.org/10.1080/014904 51.2015 .1025317

Reitschuler, C., Spötl, C., Hofmann, K., Wagner, A.O. \& P. Illmer, 2016: Archaeal distribution in moonmilk deposits from Alpine caves and their ecophysiological potential.- Microbial ecology, 71, 686-699. https://doi.org/10.1007/s00248-015-0727-z

Rusznyák, A., Akob, D.M., Nietzsche, S., Eusterhues, K., Totsche, K.U., Neu, T.R., Frosch, T., Popp, J., Keiner, R., Geletneky, J., Katzschmann, L., Schulze, E.D. \& L. Küsel, 2012: Calcite biomineralization by bacterial isolates from the recently discovered pristine karstic Herrenberg cave.- Applied and Environmental Microbiology, 78, 1157-1167. https:/doi. org/10.1128/AEM.06568-11

Sarmiento, F.B., Leigh, J.A., \& W.B. Whitman, 2011: Genetic systems for hydrogenotrophic methanogens.In: Rosenzweig, A.C. et al. (eds.) Methods in enzymology. Academic Press, 494, 43-73.

Schabereiter-Gurtner, C., Saiz-Jimenez, C., Piñar, G., Lubitz, W. \& S. Rölleke, 2002: Altamira cave Paleolithic paintings harbor partly unknown bacterial communities.- FEMS Microbiology Letters, 211, 1, 7-11. https://doi.org/10.1111/j.1574-6968.2002.tb11195.x

Shapiro J. \& A. Pringle, 2010: Anthropogenic influences on the diversity of fungi isolated from caves in Kentucky and Tennessee.- The American Midland Naturalist, 163, 1, 76-87. https://doi.org/10.1674/00030031-163.1.76

Stahl, D.A. \& J.R. De la Torre, 2012: Physiology and diversity of ammonia-oxidizing archaea.- Annual review of microbiology, 66, 83-101. https://doi. org/10.1146/annurev-micro-092611-150128

Tetu, S.G., Breakwell, K., Elbourne, L.D., Holmes, A.J., Gillings, M.R. \& I.T. Paulsen, 2013: Life in the dark: metagenomic evidence that a microbial slime community is driven by inorganic nitrogen metabolism.- The ISME journal, 7, 1227-1236. https://doi. org/10.1038/ismej.2013.14

The Human Microbiome Project Consortium, 2012: Structure, function and diversity of the healthy human microbiome.- Nature, 486, 207-214. https:// doi.org/10.1038/nature11234

Tomczyk-Żak, K. \& U. Zielenkiewicz, 2016: Microbial diversity in caves.- Geomicrobiology Journal, 33, 1, 20-38. https://doi.org/10.1080/01490451.2014.1003 341

Torsvik, V. \& L. Øvreås, 2002: Microbial diversity and function in soil: from genes to ecosystems.- Current Opinion in Microbiology, 5, 3, 240-245. https://doi. org/10.1016/S1369-5274(02)00324-7

Van Dijk, E.L., Auger, H., Jaszczyszyn, Y. \& C. Thermes, 2014: Ten years of next-generation sequencing tech- 
nology.- Trends in genetics, 30, 9, 418-426. https:// doi.org/10.1016/j.tig.2014.07.001

Wiseschart, A., Mhuanthong, W., Thongkam, P., Tangphatsornruang, S., Chantasingh, D. \& K. Pootanakit, 2018: Bacterial Diversity and Phylogenetic Analysis of Type II Polyketide Synthase Gene from ManaoPee Cave, Thailand.- Geomicrobiology Journal, 35, 6, 518-527. https://doi.org/10.1080/01490451.2017. 1411993

Wu, J.H., Chen, W.Y., Kuo, H.C. \& Y.M. Li, 2019: Redox fluctuations shape the soil microbiome in the hypoxic bioremediation of octachlorinated dibenzodioxin-and dibenzofuran-contaminated soil.- Environmental Pollution, 248, 506-515. https://doi. org/10.1016/j.envpol.2019.02.053

Yan, Y., Fu, D. \& J. Shi, 2019: Screening and Immobilizing the Denitrifying Microbes in Sediment for Bioremediation.- Water, 11, 3, 614. https://doi.org/10.3390/ w11030614
Yasir, M., 2018: Analysis of bacterial communities and characterization of antimicrobial strains from cave microbiota.- Brazilian Journal of Microbiology, 49, 2, 248-257. https://doi.org/10.1016/j. bjm.2017.08.005

Zhou, J., Gu, Y., Zou, C. \& M. Mo, 2007: Phylogenetic diversity of bacteria in an earth-cave in Guizhou Province, Southwest of China.- Journal of Microbiology, 45, 2, 105-112.

Zhao, R., Wang, H., Yang, H., Yun, Y. \& H.A. Barton, 2017: Ammonia-oxidizing Archaea dominate ammonia-oxidizing communities within alkaline cave sediments.- Geomicrobiology journal, 34, 6, 511523. https://doi.org/10.1080/01490451.2016.12258 61 